\title{
Solenn Dupas, Un art de la provocation galante: les "fleurs volcaniques et masquées» de Baudelaire
}

\section{Ida Merello}

\section{(2) OpenEdition}

1 Journals

\section{Edizione digitale}

URL: http://journals.openedition.org/studifrancesi/8992

DOI: $10.4000 /$ studifrancesi.8992

ISSN: 2421-5856

\section{Editore}

Rosenberg \& Sellier

\section{Edizione cartacea}

Data di pubblicazione: 1 octobre 2008

Paginazione: 481

ISSN: 0039-2944

\section{Notizia bibliografica digitale}

Ida Merello, «Solenn Dupas, Un art de la provocation galante: les «fleurs volcaniques et masquées» de Baudelaire», Studi Francesi [Online], 155 (LII | II) | 2008, online dal 30 novembre 2015, consultato il 12 janvier 2021. URL: http://journals.openedition.org/studifrancesi/8992 ; DOI: https://doi.org/10.4000/ studifrancesi.8992

Questo documento è stato generato automaticamente il 12 janvier 2021.

\section{(c)}

Studi Francesi è distribuita con Licenza Creative Commons Attribuzione - Non commerciale - Non opere derivate 4.0 Internazionale. 


\section{Solenn Dupas, Un art de la provocation galante: les «fleurs volcaniques et masquées» de Baudelaire}

Ida Merello

NOTIZIA

SOLENN DUPAS, Un art de la provocation galante: les «fleurs volcaniques et masquées» de Baudelaire, «Histoires littéraires», n. 31, juill-août-sept. 2007, pp. 39-50.

1 L'A. studia le interferenze tra galanteria ed erotismo nell'ambiguità testuale delle Fleurs, cercando di valutare il peso del condizionamento culturale nelle scelte poetiche. In un momento in cui Banville procede a un'epurazione degli aspetti più licenziosi dei suoi testi, Baudelaire approfondisce la trasgressione simbolica, come manifestazione di riflessioni abbozzate in De l'essence du rire sul difficile equilibrio tra la serietà e lo scherzo. 